\title{
Nadia Zebrafish
}

National Cancer Institute

\section{Source}

National Cancer Institute. Nadia Zebrafish. NCI Thesaurus. Code C79957.

A wild-type zebrafish line, the stock of which was obtained from an area east of Calcutta in a district called Nadia. 